\title{
Consumer Legal Literacy, Values and Consumerism Practices among Members of Consumer Association in Malaysia
}

\author{
Nurazlina Dol ${ }^{1}$, Elistina Abu Bakar ${ }^{2,3} \&$ Aini Mat Said ${ }^{2}$ \\ ${ }^{1}$ Department of Resource Management and Consumer Studies, Faculty of Human Ecology, Universiti Putra \\ Malaysia, Serdang, Malaysia \\ ${ }^{2}$ Centre of Excellence for Sustainable Consumption, Faculty of Human Ecology, Universiti Putra Malaysia, \\ Serdang, Malaysia \\ ${ }^{3}$ Halal Product Research Institute, Universiti Putra Malaysia, Serdang, Malaysia \\ Correspondence: Nurazlina Dol, Department of Resource Management and Consumer Studies, Faculty of \\ Human Ecology, Universiti Putra Malaysia, 43400 Serdang, Selangor, Malaysia. E-mail: ina_8908@yahoo.com
}

Received: December 6, 2014 Accepted: January 20, 2015 Online Published: April 30, 2015

doi:10.5539/ass.v11n12p189 URL: http://dx.doi.org/10.5539/ass.v11n12p189

\begin{abstract}
Self-protection is an important component that has been outlined under the Malaysian National Consumer Policy (NCP). It is essential to achieve government's vision through promoting the community of consumers who are constantly aware and knowledgeable of their rights and responsibilities. Respondents are comprised of members of consumer association (GPS) found in Institute of Higher Education. Therefore, this study aims to determine the level of consumer legal literacy, values of the consumers and their consumerism practices in the marketplace. A total of 400 respondents among the members of GPS have been selected through systematic sampling technique and the data were collected using a survey. It was found that the respondents were more aware of their rights rather than their responsibilities. Respondents also have poor in knowledge regarding logos and consumer legal literacy. While the value that possessed by the respondents is focused on the environmental values and consumerism practices are more likely to seek information. Based on profiling of the respondents, it can be concluded that the characteristics of respondents who should have given emphasis to are the member of GPS, aged between 18-20 years, studying at public universities, pursuing in Arts, member with less than one year of membership and only being ordinary members in the association. Accordingly, the results of this study can be beneficial to the government, consumer organizations and universities in the development of policy, conducting educational activities, improves the current learning modules so that consumerism programs in the future could be upgraded.
\end{abstract}

Keywords: consumer legal literacy, consumer value, consumerism practice, self-protection

\section{Introduction}

In order to increase well-being, consumers need to know their rights as well as their responsibilities in the market or being engaged in 'self-protection' as stated in the Malaysian National Consumer Association (NNA) (Jariah, Sharifah, \& Laily, 2013). Through the rationalization of National Consumer Policy (NCP), this policy is required to achieve the vision of the Malaysian government in promoting both the consumers and the suppliers who are concern and knowledgeable about their rights and responsibilities. Accordingly, Gerakan Pengguna Siswa (GPS) is established to form a group of consumers among university students who are smart, rational and responsible in the market. GPS is an initiative of the Malaysian government through the Ministry of Domestic Trade, Cooperatives and Consumerism (MDTCC) to produce citizens who are knowledgeable so that they can be the driving force in consumer education. Up until 2014, the number of GPS members has reached 25,000 people, although it has been only established in November 2011. With this amount of members, it is hope that the programs being organized are in line with the main goal of GPS to improve the consumerism knowledge gradually. Moreover, the members of GPS hopefully not only become a club member but also involved as a volunteer in any consumer association or voluntary organization after their graduation. This involvement is consumer's responsibility in engaging with consumer associations that would be implemented and become a role model to society in general. 
Furthermore, being actively involved in GPS can improve consumerism especially among university students as it is very important when they have graduated later. According to the statistics from the Department of Insolvency (2012), the number of bankruptcy has increased by 40 percent among the youth after graduation every five years and it is expected this number will reach as much as 100,000 by the year 2020 . This fact is very alarming and may occur because this people are less knowledgeable about consumer rights, information regarding the goods and services and less aware of the responsibility as a consumer to themselves, society and the environment.

Therefore, even if the GPS is newly operated, this study attempts to explore the level of consumer legal literacy and to identify their consumerism practices. Consequently, appropriate programs can be implemented in the future to make this group as an example to other consumers. Thus, the objectives of this study are to identify the level of consumer legal literacy, consumer values and consumerism practices with the aim to do the profile of GPS members.

\section{Related Previous Studies}

Consumerism practice known as any activity undertaken by people to protect their rights and interests as a consumer (Irfahani, 2009). Yet, consumerism practice in this study refers to the frequency of consumer behavior in the execution of the five responsibilities as consumer. Five responsibilities are the awareness to criticize, involvement and action, social responsibility, environmental and united as outlined by the Consumer International (CI). Responsibility of the consumer is the main focus in nurturing consumerism practice. Consumer responsibilities refer to consumer involvement in engaging consumerism activities, community, nation and environment. Based on Huda and Zulfiqar (2011), countries that have relatively stable economies such as Japan, India and Turkey make a progress in consumerism. Now, consumerism in Malaysia has grown throughout the country, but they are not the same level as in developed countries and the developing world.

For Asian countries, consumerism in India is at a stronger level than the developing countries like Pakistan. They are very concerned with customer satisfaction and consumer safety rights (Huda et al., 2011). More than 600 non-government organizations in India are actively protecting consumer interest and educating the consumer in consumerism, providing education to women in consumerism, conducting seminars and published reading materials. However, in Pakistan, they also have a lot of active consumer organizations and strong law in protecting consumer interests. There is a court in Pakistan that has been actively involved in helping the consumers to make a claim for compensation against the dealers. As results, improving in quality issues, connecting industry management code and enhancing justice for consumer (Silbey, 1981). Similarly in Turkey, a few organizations have been proven in protecting the consumer, including non-government agencies and courts. While in Japan, there are two types of consumer organizations; the organization that control product quality and advocacy group act as an advisor and protector for consumer rights. Japan is one of the Asian countries involved in the consumer organization at the international level to fight for consumer rights, consumer policy globally and policies related to the nation economy. These developments have shown awareness of consumerism in Asian countries is getting better and being actively involved.

In Malaysia, based on the study of the consumerism conducted by Jariah, Fazli and Sharifah (2013) among the rural consumers found that more than 70 percent of respondents regularly buy goods and inspect items before paying. This reflects that the consumer has the awareness to criticize quality of goods in the market. Awareness to criticize refers to the responsibility to be more alert and argue about the price and quality of goods and services supplied. Similarly to a study conducted by Jariah et al. (2013b), which also is related to the consumerism practices. Generally, the respondents have awareness to criticize than concerned about the price. The researchers suggested that consumerism practices should be seen in detail through five responsibilities as being laid down by CI which are awareness to criticize, involvement and action, social responsibility, environmental and being united.

There are two theories utilized in this study which are Empowerment Theory and Social Cognitive Theory to describe the consumerism practices. Consumerism practices in this study means to implement consumer actions in five responsibilities as a consumer based on consumer legal literacy and consumer values that they have possessed. According to the founder of Empowerment Theory, Zimmerman (1990), defines Empowerment Theory as a combination of process and outcome of the empowerment. He explained that process is referring to activity such as education programs, actions or specific authorization structure to endeavor, when the result is a stage and effectiveness empowerment power given to the individual or the community. Empowerments as a process rather than a state transition to a state unempower to empower over one's life (Zimmerman and Perkins, 1995). This theory has been used in the Basic Consumer Strategy European Unity (EU) from 2007 to 2013 
which comprised of several components which include knowledge, skills and involvement of consumer in the market (Nardo, Loi, Rosati, \& Manca, 2011). So that, two components from this theory are formed in this study which are consumer legal literacy and consumerism practices.

Consumer legal literacy refers to knowledge of GPS members towards the eight consumer rights, five consumer responsibilities, knowledge on consumer definition, legal framework of the law on goods and services, compensation mechanism and the logos as outlined by Malaysian law. Consumer knowledge is very important in any study of consumer practices (Albam \& Hutchinson, 1987). Consumers play an important role in the market because they need to communicate or express their dissatisfaction or complaints before legal action are taken (Donoghue \& De Klerk, 2009). According to Jariah et al. (2013b) the low levels of consumer knowledge in consumer rights makes it difficult for them to act as a savvy consumer. Those rights are the right to receive adequate and accurate information, the right to voice out, the right to get basic needs, the right to be protected from harmful products, the right to live and the right to work in healthy and safe environment. Based on their findings, almost half of the respondents responded all eight consumer rights correctly, but there were respondents responded to other statements that are not consumer rights. This indicates that the level of the consumer knowledge is still at low level.

Therefore, the consumer is expected to have knowledge regarding their rights, for example, complaints procedure and appropriate action in accordance with the legislations. However, there is certain time the law is not the best way to protect consumer rights, but depends on the consumers themselves (Sakina, Suzanna, \& Azimon, 2012). Thus, consumers must actively participate in supporting the enforcing process of their rights against exploitation market. This is because the low level of consumerism cause difficulties in self-defense against the cunning merchants and may cause deterioration of the consumers' ability to carry out their rights as a consumer and also failed to force the dealer to act accordingly (Suraiya \& Nur Faridah, 2012). This problem not only occurs in Malaysia, but in Turkey as well. According to a research by Kaynak, Kucukemiroglu and Odabasi (1992), the number of compensation claims has increased since 1981. This indicates that Turkey consumers are increasingly focused on their rights as a consumer. Besides consumer rights that are recognized around the world, consumers also at the same time should fulfill their responsibility to produce balanced and responsible consumer in the market. Past research demonstrates that consumer behavior is influenced by value, attitude and knowledge (Laroche, Bergeron, \& Barbero-Folio, 2001). Due to these aspects, especially knowledge guides consumer in decision-making, the level of knowledge towards sustainability consumerism is vital.

Besides that, Social Cognitive Theory asserts learning concept in a social context that is, a reciprocal interaction or triangular relationship between individual factors, environment and behavior (Wood \& Bandura, 1989). There are several components in the individual factors which are cognitive, affective, motivation, skills, and self-efficiency. However, these studies only focus on cognitive and affective components. The cognitive component is related to the knowledge whether they know or not about consumerism which will give the impression to their consumerism practices. However, affective component is consumer acceptance of something cause based on the values held by them. Two components are formed in these studies which are knowledge and consumer values.

Consumer value which is a new element in the NCP 2010, is an important principle drives the consumer towards a prosperous life in the market. Consumer values refer to the principles held by the consumer based on the five basic values that should be held by the consumer accordingly; (as responsible consumers, we must ensure that our consumption patterns and lifestyles do not contribute to the economic exploitation and oppression that disregard human and humane values), money (consumers must ensure that for the benefit of all they should not contribute to any loss in the value of our hard-earned income brought about by indiscriminate purchases and wasteful spending habits), environment (the pre-condition for the life-support system to continue to function is an ecologically balanced environment that is able to regenerate itself on an uninterrupted, continuous basis), democracy (as members of the civil society, consumers give the mandate to members of civil society through the process of election to govern them. Government in a democracy is the servant of the people, and citizens as consumers have a right to government services that are responsible, transparent and accountable) and justice value (consumers, through their role as consumers and citizens, owe a responsibility to ensure value for justice, not only for ourselves as consumers but also for the trader, the investor and others involved in the economic and social system) (Fazal \& Bishan, 1991). These values are introduced by Bishan one of the prominent consumerism figure in Malaysia which are capable of influencing consumer practices and decision-making. Tabara and Giner (2004) stated that, high knowledge level accompanied by values and cultural perspective is the main essence to educate people in the modern society. Jariah et al. (2013b) conducted a study among Malaysian consumers regarding consumer well-being found that consumers are more focus on value of money instead of 
higher values like environment and justice value. However, consumers should appreciate of each the value so that consumer rights and responsibilities go hand in hand, while to ensure self-protection that will be done by the consumer is effective.

\section{Methodology}

The dependent variable in this study is consumerism practice refers to the frequency of behavior or consumer action in implementing consumer responsibility based on five responsibilities outlined by the International Organization of Consumer Union (IOCU) or now is known as the Consumer International (CI). On the other hand, independent variables are consumer legal literacy and consumer value. Consumer legal literacy is knowledge related to the eight consumer rights, five consumer responsibilities and basic consumerism laws outlined under the Malaysian Consumer Protection Act (CPA) 1999, including the implied guarantees relate to goods and compensation mechanisms. Consumer value is based on five basic values should be held by the consumer. The value consists of value of human beings, money, environment, democracy and justice (Fazal \& Bishan, 1991).

\subsection{Sampling}

Data were collected through a survey using questionnaire at few of Institute of Higher Learning (IHL) in the Northern, Western, Eastern and Southern zone of Peninsular Malaysia and Sabah and Sarawak. There are ten institutions being selected among GPS in the list issued by Ministry of Domestic Trade, Cooperatives and Consumerism (MDTCC) using simple random sampling. After that, a total of 400 respondents among the members of the GPS in ten institutions were selected by systematic sampling technique. Data collected were self-administered and questionnaires were filled out by respondents themselves. The data were collected from $30^{\text {th }}$ September and ends on $28^{\text {th }}$ November 2013.

\subsection{Measurement}

The instrument consists of four parts, namely Section A, the background of the respondents, Section B, consumer legal literacy, Section C, and Section D are consumer value and consumerism practice respectively. In Section B, consumer legal literacy (consumer rights, consumer responsibility, knowledge on consumer definition and legal framework, knowledge on the laws regarding goods and services, knowledge on redress mechanism, Halal and safety logo). The question is a closed-ended question with "right" and "wrong" responses and fill in the blanks for open-ended questions, while Section C, questions are in Likert scale of 5, "1 = strongly disagree" to "5 = strongly agree". In Section D, a 4 Likert scale response were asked from "1 = never" to "4 = always". Questions were adopted from previous study which are Naemah, Elistina and Azimon (2012) based on consumer law under the CPA 1999. While questions about the consumer value is modified based on the five basic consumer proposed by Fazal et al. (1991) which are human, money, environment, democracy and justice value.

The questions in consumerism practices were based on the five responsibilities listed by CI. Consumerism practices portion comprised of 17 items practice has been analyzed using factor analysis. According to factor analysis, there are five dimensions being produced which are the practices of expression, information seeking, sensitivity before purchasing, concern towards consumerism issues and involvement in consumerism activities. Expression dimension refers to the practice of voicing out opinion, dissatisfaction, share their views and made complaints. Whereas, seeking information is about the practices in comparing prices and obtains products information before purchasing. Practices such as reading labels, utility bills and the terms and conditions of the agreement before the purchasing can be referred to dimension of sensitivity before purchasing.

Reliability testing was performed using Cronbanch's Alpha Reliability Test. This test was conducted twice after the pre-test and the second time after the completion of actual data collection. Both results find the instrument reliability is reliable with alpha value of 0.937 for consumer value, while consumerism practices of 0.917 .

A pilot test was conducted on 20 respondents. The Cronbanch alpha showed satisfactory internal consistency score ranged from 0.91 to 0.93 (Table 1).

Table 1. Reliability score

\begin{tabular}{ccc}
\hline Construct & Cronbach Alpha (Pilot) & Cronbach Alpha (Post) \\
\hline Consumer' values & 0.937 & 0.795 \\
Consumerism practices & 0.917 & 0.840 \\
\hline
\end{tabular}

\subsection{Analysis}

Data were analyzed using the Statistical Package for Social Science (SPSS) and discussed in descriptive analysis in order to explain the background of the respondents. Chi Square test (Pearson Chi-Square) was used in this 
study to carry out the profiling of respondents in consumer legal literacy, consumer value and consumerism practice among GPS.

\section{Results}

\subsection{Background of Respondents}

Based on Table 2, a total of 34.8 percent of the respondents were male and 65.3 percent were female, with the largest age percentage was between 18-20 years with 52.3 percent. Most of the respondents were Malay, (79.5\%) followed by 13.8 percent were Chinese. Total number of ethnicity revealed that majority of the members in GPS was Malay which consistent with the population in Malaysia because most of the population is Malay. The respondents were comprised of 77.8 percent of public university students with 81.0 percent of them pursuing a bachelor degree. Three quarter of them were studying in Arts stream (76.5\%) whereby 42.8 percent of them were in Year 1. From the total population of respondents, duration as a club member was mostly between 1 and 2 years $(40.5 \%)$. The majority, more than three quarter of the respondents $(87.8 \%)$ only became an ordinary member of the consumer club (GPS).

Table 2. Background of Respondents

\begin{tabular}{|c|c|c|}
\hline Characteristics & Frequency & Percent $(\%)$ \\
\hline \multicolumn{3}{|l|}{ Gender: } \\
\hline Male & 139 & 34.8 \\
\hline Female & 261 & 65.3 \\
\hline \multicolumn{3}{|l|}{ Age: } \\
\hline $18-20$ & 209 & 52.3 \\
\hline $21-24$ & 180 & 45.0 \\
\hline $25-27$ & 11 & 2.8 \\
\hline \multicolumn{3}{|l|}{ Ethnicity: } \\
\hline Malay / Bumiputera & 318 & 79.5 \\
\hline Chinese & 55 & 13.8 \\
\hline Indian & 16 & 4.0 \\
\hline Others & 11 & 2.8 \\
\hline \multicolumn{3}{|l|}{ Institute of Higher Education: } \\
\hline Public University & 311 & 77.8 \\
\hline Private University & 89 & 22.3 \\
\hline \multicolumn{3}{|l|}{ Education Level : } \\
\hline Diploma/Certaficate/STPM & 71 & 17.8 \\
\hline Bachelor & 324 & 81.0 \\
\hline Master/PhD & 5 & 1.3 \\
\hline \multicolumn{3}{|l|}{ Field of Study: } \\
\hline Sciences & 94 & 23.5 \\
\hline Arts & 306 & 76.5 \\
\hline \multicolumn{3}{|l|}{ Year of Study: } \\
\hline Year 1 & 171 & 42.8 \\
\hline Year 2 & 137 & 34.3 \\
\hline Year 3 & 65 & 16.3 \\
\hline Year 4 & 27 & 6.8 \\
\hline \multicolumn{3}{|l|}{ Membership: } \\
\hline$<1$ year & 149 & 37.3 \\
\hline 1-2 year & 162 & 40.5 \\
\hline$>2$ year & 81 & 21.0 \\
\hline \multicolumn{3}{|l|}{ Club Role: } \\
\hline Committee member & 46 & 11.5 \\
\hline Member & 351 & 87.8 \\
\hline
\end{tabular}

\subsection{Consumer Legal Literacy}

Consumer legal literacy can be divided into six parts; consumer rights, consumer responsibility, definition and legal framework, law on goods and services, compensation mechanism and logos.

Based on Table 3, the results show that the highest mean is on the consumer rights, which is 0.78 . Nevertheless, the lowest mean is knowledge towards Halal logo and safety with 0.32 . 
Table 3. Mean knowledge of consumer legal literacy

\begin{tabular}{lcc}
\hline Dimension & Mean & SD \\
\hline Consumer rights & 0.78 & 0.14 \\
Consumer responsibility & 0.67 & 0.15 \\
Knowledge on consumer definition and legal framework & 0.58 & 0.23 \\
Knowledge on the laws regarding goods and services & 0.52 & 0.17 \\
Knowledge on redress mechanism & 0.62 & 0.13 \\
Knowledge on Halal and safety logo & 0.32 & 0.19 \\
\hline
\end{tabular}

\subsection{Consumer Value}

Consumer value is one of the variables studied in this research. There are five basic values proposed by Fazal $\&$ Bishan (1991), which are the value of human, money, environment, democracy and justice. Based on Table 4, most of the consumer value possessed by the respondents is environmental value with the mean of 4.59 , while the value of money is the lowest value with the mean of 3.86 .

Table 4. Mean of consumer value

\begin{tabular}{ccc}
\hline Dimension & Mean & SD \\
\hline Money value & 3.86 & 0.86 \\
Human value & 4.08 & 0.81 \\
Democracy value & 4.36 & 0.67 \\
Justice value & 4.38 & 0.66 \\
Environmental value & 4.59 & 0.56 \\
\hline
\end{tabular}

\subsection{Consumerism Practice}

Based on Table 5, the results show the mean of consumerism practice according to five dimensions. Results signified that the mean of seeking information dimension is the highest which is at 3.34 , followed by sensitivity before purchasing at 3.17. The lowest mean were dimension of expression and participation in consumerism activities with 2.58 respectively. Responses were also low in expressing opinion on certain things associated with consumerism.

Table 5. Mean of consumerism practices

\begin{tabular}{lcc}
\hline Dimension & Mean & SD \\
\hline Expression & 2.58 & 0.74 \\
Seeking information & 3.34 & 0.64 \\
Sensitivity before purchasing & 3.17 & 0.72 \\
Concern over consumerism issue & 2.84 & 0.65 \\
Involving in consumerism activities & 2.58 & 0.63 \\
\hline
\end{tabular}

\subsection{Summary of Respondents Profile on Consumer Legal Literacy, Consumer Values and Consumerism Practice}

Based on Table 6, a summary profile of the respondents on consumer legal literacy, consumer values and consumerism practices have been produced. Profile has been set up just for people who need more exposure in consumer education which are for those with low level of knowledge, negative consumer value and negative consumerism practice. Each level is determined by adding all the scores for each item and then divided into several groups based on percentile, i.e. $25 \%, 50 \%$ and $75 \%$. Socio-demographics studied were gender, age, ethnicity, Institute of Higher Learning, education level, year of study, field of study, club membership and club role position by using Chi Square test (Pearson Chi-Square). For the low level of knowledge, only age, year of study, club membership and club role has a significant differences regarding consumer legal literacy. Based on Chi Square test $\left(\chi_{2}=3.233\right)$ represents that there is a significant differences in the age regarding consumer legal literacy $(\mathrm{p}=.000)$. The study found that the respondents between 18 to 20 years were at the lowest level with 52.2 percent. This shows that for those aged 18 to 20 years who were at matriculation and diploma level or can be known as A-level, still has less exposure related to legal literacy since they were newly involved in GPS. Therefore, they need to be addressed in terms of consumer legal literacy so that they can obtain the same level of knowledge with the older age groups through a variety of programs that will be organized in the future. 
Next, for the year of study, test of Chi Square $\left(x^{2}=16,894\right)$ denotes that there is significant differences with the level of consumer legal literacy $(\mathrm{p}=.000)$. This study found, students in Year 1 and 2 are located on the lower level of knowledge with a total of 46.1. These results indicate that students in Year 1 to 2 are still new to consumerism and thus low in consumer legal literacy.

Chi Square $\left(\chi^{2}=20.885\right)$ result also stated that the duration of membership variables has significant differences with the level of consumer legal literacy $(\mathrm{p}=.000)$. The study found, for those acquired membership less than 1 year has the lowest level of knowledge at 45.8. Logically, the level of involvement affects their knowledge about consumerism and it is proven in this study. Those become a member less than one year has a low level of knowledge than those who have long been involved in the consumer club. This may be due to the adoption from various source of knowledge through consumer education programs. Anyhow, it needs to be improved so that they are totally well-versed in consumer legal literacy and then practice it in their daily life. Thus, GPS member can act as an example to friends and family members as well as the consumers in general.

Table 6. Summary profile of consumer towards consumer legal literacy, consumer values and consumerism practice

\begin{tabular}{|c|c|c|c|}
\hline Socio-demographic & $\begin{array}{c}\text { Low level of consumer law } \\
\text { knowledge }(n=166)\end{array}$ & $\begin{array}{c}\text { Negative value of consumer } \\
\text { value }(n=202)\end{array}$ & $\begin{array}{l}\text { Negative consumerism } \\
\text { practice }(n=210)\end{array}$ \\
\hline \multicolumn{4}{|l|}{ Gender } \\
\hline Male & $56(40.3)$ & $81(60.0)$ & $77(55.4)$ \\
\hline Female & $110(42.1)$ & $128(49.0)$ & $133(51.0)$ \\
\hline Sig. (p) & 0.278 & $0.015 *$ & 0.397 \\
\hline$x^{2-(4)}$ & 2.557 & 5.914 & 0.716 \\
\hline \multicolumn{4}{|l|}{ Age } \\
\hline $18-20$ & $109(52.2)$ & $109(52.9)$ & $115(55.0)$ \\
\hline $21-27$ & $37(45.1)$ & $93(50.0)$ & $95(49.7)$ \\
\hline Sig. (p) & $0.000 * *$ & 0.564 & 0.290 \\
\hline$x^{2}$ & 3.233 & 0.332 & 1.118 \\
\hline \multicolumn{4}{|l|}{ Ethnicity } \\
\hline Malay & $129(40.6)$ & $161(51.8)$ & $171(53.8)$ \\
\hline Non Malay & $37(45.1)$ & $41(50.6)$ & $39(47.6)$ \\
\hline Sig. (p) & 0.199 & 0.853 & 0.315 \\
\hline & 3.233 & 0.034 & 1.009 \\
\hline \multicolumn{4}{|l|}{$\begin{array}{l}X \\
\text { Institute of Higher Learning }\end{array}$} \\
\hline Public university & $131(42.1)$ & $159(52.3)$ & $168(54.0)$ \\
\hline Private university & $35(39.3)$ & $43(48.9)$ & $42(47.2)$ \\
\hline Sig. (p) & 0.863 & 0.570 & 0.255 \\
\hline$x^{2}$ & 0.294 & 0.323 & 1.294 \\
\hline \multicolumn{4}{|l|}{${ }^{\chi}$ Education Level } \\
\hline Diploma & $35(49.3)$ & $43(61.4)$ & $35(49.3)$ \\
\hline Bachelor/ Master/PhD & $131(39.8)$ & $159(49.4)$ & $175(16.7)$ \\
\hline Sig. (p) & 0.328 & 0.068 & 0.551 \\
\hline$x^{2}$ & 2.231 & 3.343 & 0.355 \\
\hline \multicolumn{4}{|l|}{ Year of Study } \\
\hline Year 1-2 & $142(46.1)$ & $156(51.8)$ & $169(54.9)$ \\
\hline Year 3-4 & $46(50.5)$ & $46(50.5)$ & $41(44.6)$ \\
\hline Sig. (p) & $0.000 * *$ & 0.831 & 0.082 \\
\hline & 16.894 & 0.046 & 3.017 \\
\hline \multicolumn{4}{|l|}{ Field of Study } \\
\hline Sciences & $43(45.7)$ & $51(54.8)$ & $46(53.6)$ \\
\hline Sastera & $123(40.2)$ & $151(50.5)$ & $164(54.2)$ \\
\hline Sig. (p) & 0.617 & 0.465 & 0.429 \\
\hline$x^{2}$ & 0.967 & 0.534 & 0.626 \\
\hline \multicolumn{4}{|l|}{ Membership } \\
\hline$<1$ year & $142(45.8)$ & $161(53.1)$ & $168(54.2)$ \\
\hline$>1$ year & $24(26.7)$ & $41(46.1)$ & $42(46.7)$ \\
\hline Sig. (p) & $0.000 * *$ & 0.241 & 0.208 \\
\hline$x^{2}$ & 20.885 & 1.376 & 1.585 \\
\hline \multicolumn{4}{|l|}{ Club Role } \\
\hline Committee & $14(30.4)$ & $18(39.1)$ & $19(41.3)$ \\
\hline Member & $151(43.0)$ & $184(53.6)$ & $190(54.1)$ \\
\hline Sig. (p) & $0.029 *$ & 0.064 & 0.101 \\
\hline$x^{2}$ & 7.057 & 3.423 & 2.684 \\
\hline
\end{tabular}

*Significant (two-tailed) at $\mathrm{p}<.05 ; * *$ Significant (two-tailed) at $\mathrm{p}<.01$ 
Lastly, Chi Square $\left(x^{2}=7.057\right)$ results magnify that there is significant differences between club role variable and the level of consumer legal literacy $(p=.029)$. The study found that being as an ordinary member was at low level of knowledge (43.0\%). Thus, the ordinary members should be given priority in order to increase consumer legal knowledge compared to committee members. However, other socio-demographic characteristics such as gender, ethnicity, Institute of Higher Learning, level of education and field of study did not show a significant difference, consequently an equal exposure should be given to all.

For the profile of the respondents associated with negative consumer value, only gender has the significant result in respect of consumer value. Based on the results Chi Square $\left(\chi_{2} 2=5.914\right)$ test showed that there is significant differences in the variables of gender on consumer value $(p=.015)$. The study also found that, the score of consumer value among male at the negative value score of 60 percent. Therefore, male should be emphasized in inculcating good consumer value in the future where as other socio-demographic characteristics should be given equal emphasis.

In terms of socio-demographic, study by Dutton, Salleh and Ahmad (2011), found that most female respondents in Bandar Baru Bangi and Kajang have make a claim directly to the consumer tribunal compared to male respondents. This may due to female respondents are more concerned or fussy and more sensitive when they experience dissatisfaction while shopping. Similarly, a study conducted by Curt and Gross (2003) found that demographic factors such as gender affect consumer knowledge. It seems that only male and young consumers who are prone to protect their consumer rights.

The profile of consumerism practice showed that no significant results. Hence, all the features in the socio-demographic characteristics as specified in the table should be emphasized equally in order to improve their practices in consumerism evenly without any exception. While related to sustainable practices, Farhan and Mumtazah study (2010), found that student's background factors, such as where the respondent was raised and ethnicity affects the sustainable practices of the respondents and found that rural respondents contribute the most in reducing and recycling when scored high in positive statements in contrast to the respondents living in the city.

\section{Discussions}

Referring to the descriptive analysis of consumer legal literacy, most respondents knew about consumer rights. On the contrary, the results conducted by Jariah et al. (2013b) study found that less than one third of respondents knew about all the eight consumer rights that have been long introduced. In the same study, they found that without knowing the consumer rights, consumers certainly do not know about their responsibilities as a consumer and will not be able to fulfill the government's efforts to enhance their self-protection. The lowest mean score shows that most of the respondents have less knowledge about Halal logo and safety. For example, there were still many respondents who were unable to compare the Halal logo issued by Department of Islamic Development Malaysia (JAKIM) and could not identify 'EU Standards logo' (CE) perfectly. This study also found that respondents were more likely to hold environmental value, when most of the respondents agreed that the practice of recycling is necessary to ensure their well-being. Overall, respondent's value of consumer indicated that they held onto more environment value rather than money, humanity, democracy and justice.

Meanwhile, the results of this study also contradict with the findings of Amim and Sharifah (2006) which disclosed that the level of consumer knowledge on the Halal logo is high in which 233 respondents $(75.4 \%)$ can recognize the logo. They knew the logo issued by the relevant authorities, whether from within the country or abroad, and only a total of 76 respondents (24.6\%) did not know the Halal logo issued by the authorities. According to Mohd Ali and Nor Aini (2010), among the consumerism issues are consumer confused with various forms of Halal logo used in the market as one of the causes of consumer less knowledgeable about Halal logo issued by the authorities. Consumers often fail to identify the genuine Halal logo. Diversity of Halal logo has affected the buyer's decision to purchase Halal products (Sanep, Hairunizam \& Surtahman, 2007). Overall, this study showed that respondent knowledge is very basic which solely focus on the eight consumer rights against other knowledge. Therefore, it is about time for the government and consumer associations to change the direction of implementing consumer education program to the next level with wider consumerism knowledge and not only focus on the eight rights alone.

Based on the result of consumer value, the respondents have a good value in all the five values that are important to consumer. Yet, respondents were more focused on the environmental value and less towards the value of money. These values should be balanced with each other, especially the value of money since it is related to the right to get basic consumer needs. This can be achieved if the consumer themselves carry responsibility through their usage of money. These results are in contrast to Jariah et al. (2013b) findings; the consumers generally put 
high importance in spending wisely, non materialistic and ensure that the money they spend is worth it. Thus, the consumers need to ensure that the money spent does not contribute to any loss of their overall income value. Appreciation of the value of money can help in reducing the occurrence of bankruptcy, especially to young people. Accordingly, respondents still need to hold consumerism values equally and it is hoped that through educational programs in universities and consumerism activities organized by the ministry and consumer associations, it can inculcate good value to all GPS students.

Next, respondents were more towards seeking information dimension for consumerism practice and followed by sensitivity before purchasing, concerns over consumerism issue, expression and involvement in consumerism activities. This study was supported by Jariah et al. (2013) research that related to the basic practices of consumerism in the rural consumer which found that more than 70 percent of respondents regularly buy goods with high quality standards and inspects the items before purchasing. This shows that the consumers have the awareness to criticize in the market. Awareness towards criticism refers to the responsibility to be more aware and curious about the price and quality of goods and services being used. A responsible consumer should not be silent, but to voice out for the good quality of goods and services at reasonable price. Thus, consumerism practice is becoming steadily important to consumers themselves, society, nation and environment. If observed in detail, the results show that consumerism practice pattern among the respondents was more prone to activities involving themselves compared to activities involving consumers and society at large.

Last but not least, as a results from the respondents profiling, characteristics of respondents should be emphasized to all demographic characteristics regarding consumer legal literacy except, for those by the age between 18-20 years, between $1^{\text {st }}$ and $2^{\text {nd }}$ year of study, membership less than one year and as an ordinary member without any role in the club. Meanwhile, efforts to increase consumer value and consumerism practice should be emphasized equally to all demographic characteristics, except for female in consumer value.

\section{Conclusion}

This study is important because it provides some implications to the GPS members itself, government, consumer associations and universities. Among all, findings of this study can be used as a guide to the government, especially MDTCC to drive GPS in Malaysia in terms of more active education programs, especially efforts to increase consumer legal literacy among GPS members so that they understand better regarding consumer legal literacy especially in reading the Halal and safety logo. Government should formulate and organize programs related to knowledge on labeling especially on food packaging or other items. This is because these skills are very important for the consumers themselves in evaluating each item particularly on Halal and safety issues, such as electrical and electronic appliances. Knowledge in labeling is vital in food choice even if those actions seem simple, but the contribution towards assisting in making healthy food choices or better product are very important (Cowburn \& Stockly, 2004). In addition, it also helps in making comparisons with other items. However, knowledge acquired by the respondents hopefully will be applied and shared with other university students and the community in general.

Additionally, the value hold by each consumer is important. Based on the results of this study clearly shows that the respondents' value of consumer are focused more on environmental value and less on value for money. This indicates that respondents are less focused on financial management so they would suffer a loss because of their poor financial planning. However, as we all know, it is not easy to change the value of a person and it requires careful planning and ongoing program for inculcating a balanced consumer value. Among the programs to be implemented are related to the preparation of expenditure, financial management, balancing between income and expenses and so on. Failure in good financial management is likely to lead more young people involved in bankruptcy.

The findings can also be used by the consumer associations in Malaysia because they are also active members in consumerism. Consumer associations are also seen as an organization that can play a role to make improvements by providing training and information to GPS members in their activities. These improvements can be focusing on the content of the program. In addition, consumer associations can also adopt the GPS members so that they can be actively involved in the association even after graduation and thus be able to contribute ideas and energy to the association in the future.

Finally, the results from the analysis of consumerism practices displayed the lacking of GPS members to participate in consumerism activities. This is something that should be taken seriously because of the level of measurement is measured subjectively, which indicates that respondents personally felt that they were less involved in consumerism activities. Workshops and seminars as well as a special course focusing on the consumerism practices through their role or responsibilities as consumers should be frequently conducted. The 
government also is proposed to intensify efforts in educating the consumer about the importance of these consumerism practices, as well as promoting their practices through the mass media. This study will also be beneficial to the university, particularly club advisor in organizing activities that are more appropriate and beneficial to the members of the club. For example, conducting educational activities, in line with the learning modules and programs related to consumerism (workshops, seminars, lectures by consumerism experts, brochures publication, newsletters) in the future. Similarly, it is also suggested that primary and secondary school curriculum need to be revised to include knowledge of consumer education, consumer value and consumerism practice in their education systems. Education at this early stage is very important to impart knowledge and inculcate value of students who are also consumers when they grow up. In this aspect, the teacher plays an important role in guiding and encouraging the younger generation to be prepared in terms of knowledge on consumerism while at the same time practices consumerism actively and consistently.

\section{References}

Ahmad Hariza, H. (2002). Peranan dan tanggungjawab Persatuan Pengguna. Pengenalan Sains Pengguna, (8), 136-147.

Albam J. W., \& Hutchinson, W. (1987). Dimension of consumer expertise. Journal of Consumer Research, 13(4), 411-454.

Consumers Association of Penang. (2002). Pengguna dilindungi pelbagai akta. Retrieved from http://www.utusan.com.my/utusan/Rencana/20120425/re_06/Pengguna-dilindungi pelbagai-akta

Cowburn, G., \& Stockly, L. (2004). Consumer understanding and use of nutrition labeling: A systematic review. Public Health Nutrition, 8(1), 21-28. http://dx.doi.org/10.1079/PHN2004666

Curt, J. D., \& Gross, B. L (2003). What consumers know and what they do: An investigation of consumer knowledge, awareness and use of privacy protection strategies. Journal of Interactive Marketing, 17(2), 34-51. http://dx.doi.org/10.1002/dir.10053

Donoghue, S., \& De Klerk, M. (2009). The right to be heard and to be understood: A conceptual framework for consumer protection in emerging economies. International Journal of Consumer Studies, 33(4), 456-467. http://dx.doi.org/10.1111/j.1470-6431.2009.00773.x

Endut, W., Salleh, K. M., \& Asri, N. M. (2011). Kepekaan terhadap hak membuat tuntutan gantirugi. Malaysian Journal of Consumer and Family Economics, 14, 76-93.

Fardini, Z., Laily, P., \& Husniyah, A. R. (2010). Perbandingan literasi kewangan siswa berasaskan gender. Jurnal Pengguna Malaysia, 15, 50-64.

Farhan, M. A., \& Mumtazah, O. (2010). Sikap mahasiswa terhadap penggunaan lestari. Jurnal Pengguna Malaysia, 14, 110-121.

Fazal, A., \& Bishan, S. (1991). Consumer education: A resource book. Malaysia.

Fazli, S., \& Yong, T. Y. (2006). Tahap keprihatinan alam sekitar dan amalan kepenggunaan hijau pengguna di Petaling Jaya, Selangor. Pertanika Journal of Social Science \& Human, 14(2), 95-109.

Fazli, S., Husniyah, A. R., Hariza, H., Amim, O., \& Syuhaily, O. (2004). Sikap dan amalan pengguna di Sabah dan Sarawak terhadap pinjaman perumahan. Malaysian Journal of Consumer and Family Economics, 7, 89-101.

Huda, K., \& Zufiqar, A. K. (2011). Consumerism in Asia. Journal of Marketing Philosophy \& Practice, 1(1), $1-9$.

Jabatan Insolvensi. (2012). Statistik Jabatan Insolvensi Malaysia Januari hingga September 2013: Seramai 16,306 orang telah diisytiharkan muflis. Retrieved from http://idaman78.blogspot.com/2014/02/ statistikjabatan insolvensi-malaysia.html

Jariah, M., Fazli, S., \& Sharifah, A. H. (2013a). Cabaran pengguna luar bandar. In Z. Zumilah, A. B. Elistina, \& Z. Nor Rashidah (Eds.), Malaysia negara maju: Realiti dan cabaran pengguna (pp. 54-57). Serdang: Malaysia.

Jariah, M., Sharifah, A. H., \& Laily, P. (2013b). Realiti keupayaan pengguna Malaysia. In Z. Zumilah, A. B. Elistina, \& Z. Nor Rashidah (Eds.), Malaysia negara maju: Realiti dan cabaran pengguna (pp. 21-27). Serdang: Malaysia.

Kaynak, E., Kucukemiroglu, O., \& Odabasi, Y. (1992). Consumer complaint handling in an advanced developing 
economy: An empirical investigation. Journal of Business Ethics, 11, 813-829.

Laroche, M., Bergeron, J., \& Barbaro-Forleo, G. (2001). Targeting consumers who are willing to pay more for environmentally friendly products. Journal of Consumer Marketing, 18(6), 503-520. http://dx.doi.org/10.1108/EUM0000000006155

Ministry of Domestic Trade, Co-operatives and Consumerism. (2012). Dasar Pengguna Negara. Retrieved from http://www.kpdnkk.gov.my/kpdnkk/dasar kementerian/pengguna-negara

Mohd Ali, N., \& Nor Aini, H. I. (2010). Isu dan faktor pilihan pengguna muslim terhadap produk makanan dan barangan halal di Malaysia. Proceedings of the 14th National Seminar MACFEA (pp. 447-455). Serdang: Malaysia.

Naemah, A., Azimon, A. Z., \& Elistina, A. B. (2012). Kajian literasi undang-undang pengguna dalam kalangan pelajar IPTA. Seminar Penyelidikan Kepenggunaan 2012 (pp. 23-27). Universiti Putra Malaysia: Serdang.

Nardo, M., Loi, M., Rosati, R., \& Manca, A. (2011). The consumer empowerment index. A measure of skills, awareness and engagement of european consumers European Union. Journal of Religion and Culture, 1-233. http://dx.doi.org/10.2788/9102

Norhasmah, S., Aini, M. S., Laily, P., Sharifah, A. H., Nurizan, Y., \& Naimah, S. (2004). Sikap dan amalan terhadap keprihatinan persekitaran. Malaysian Journal of Consumer and Family Economics, 7, 54-65.

Rachagam, S. S. (1992). Consumer law report United Nations development programme and Selangor and Federal Territory consumer (p. 199). Association. University of Malaya Press. Universiti Malaya.

Sakina, S. A. Y., Suzanna, M. I., Azimon, A. A., \& Ong, T. C. (2012). Corporate responsibility via Malaysian contract law: A concern for consumer protection. Pertanika Journal of Social Sciences and Humanities, 20(1), 227-238.

Sanep, A., Hairunizam,W., \& Surtahman, K. H. (2007). PKS di persada dunia melalui tanda halal: Kes gelagat pengguna. In N. M. Noorizuddin (Ed.), Penjenamaan Halal Satu Paradigma Baru (pp. 71-98). Universiti Sains Islam Malaysia: Malaysia.

Sarah S. (2012). Mahasiswa UMP meriahkan Karnival Gerakan Pengguna. Unit Perhubungan Awam \& Media Pejabat Naib Canselor Siswa. Retrieved from http://community.ump.edu.my/ecommstaff/includes/view NewsToPublic.jsp?ref $=8867$

Shamsul, A. Z. B., Naimah, M. S., Amim, O., \& Sharifah, A. H. (2006). Tahap pengetahuan pengguna terhadap konsep halal dan haram serta penggunaan bahan tambah (food addities) dalam makanan. Jurnal Pengguna Malaysia, 8, 58-67.

Silbey, S. S. (1981). Consumer protection. Law and Society Review, 15(3-4), 849-882.

Singla, M. (2010). Usage and understanding of food and nutritional labels among Indian consumers. British Food Journal, 112(1), 83-92. http://dx.doi.org/10.1108/00070701011011227

Suraiya, I., \& Nur Faridah M. Z. (2012). Impact of consumer awareness and knowledge to consumer effective behavior. Asian Social Science, 8(13), 108-114. http://dx.doi.org/10.5539/ass.v8n13p108

Tabara, \& Giner. (2004). Diversity, civic virtues and ecological austerity. International Review of Sociology. 14(2). http://dx.doi.org/10.1080/03906700410001681329

Zimmerman, M. A. (1990). Taking aim on empowerment research: On the distinction between individual and psychological conceptions. American Journal of Community Psychology, 18(1), 169-177.

Zimmerman, M. A., \& Perkins, D. D. (1995). Empowerment theory, research and application. American Journal of Community Psychology, 23(5), 569-578.

\section{Copyrights}

Copyright for this article is retained by the author(s), with first publication rights granted to the journal.

This is an open-access article distributed under the terms and conditions of the Creative Commons Attribution license (http://creativecommons.org/licenses/by/3.0/). 